\title{
口腔領域悪性黒色腫の臨床的検討
}

\author{
田中信幸・天笠光雄・岩城博・謝䋸鋢

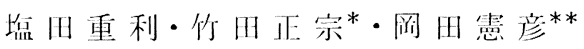

\section{Clinical investigation of malignant melanoma in oral region}

\author{
Nobuyuki Tanaka - Teruo Amagasa - Hiroshi Iwaki \\ Kuo Jeng Hsien - Shigetoshi Shioda - Masamune Tikeda* \\ Norihiko OKadA**
}

\begin{abstract}
Clinical examination was performed in 20 cases of malignant melanoma in the oral region encountered in the First Department of Oral and Maxillofacial Surgery, Faculty of Dentistry, Tokyo Medical and Dental University during the 20-year period from 1970 to 1989. The following results were obtained;

1. The incidence of malignant melanoma in the oral region was not different between sexes. The tumor was observed mostly in the maxilla and palate.

2. From the macroscopic findings the tumors were classified into 5 types as follows; 1 ) Black nodule type, 2) Non-pigmented nodule type, 3) Radial growth phase type, 4) Black mixed type, and 5) Non-pigmented mixed type. The clinical course of the non-pigmented nodule type was relatively bad, while that of the radial growth phase type was good.

3. The clinical course of malignant melanoma in the oral region was generally worse than those of oral squamous cell carcinoma and salivary gland carcinoma. Radiotherapy seemed to be effective in prolonging the life of these patients.
\end{abstract}

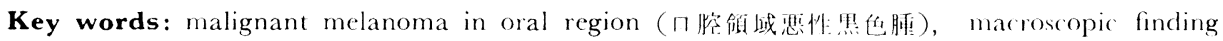
(肉揤所見)，radiotherapy（放射線撩法）

緒 言

口腔領域の悪性黑色腫は，丽平上皮癌や腺系腫序など に比べてきわめてまれな疾患ではあるが，その悪性度は 高く，治摺成績は不良な症例が多い。皮膚科領域の悪性 黑色腫については数多くの研究報告をみるが，口腔領域 のものについてはまだ数少なく，その治療法は確立され ているとはいえない，今回われわれは，当科に扣ける口

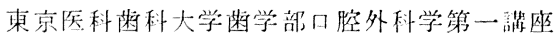
(主任：塩田重利教授)

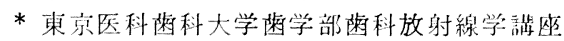
（主任：佐々木武仁教授）

**東京医科俻科大学楼学部附属病院榆查部 （主任：塩田重利教授）

The First Department of Oral and Maxillofacial Surgery, Faculy of Dentistry, Tokyo Medical and Dental University (Chief: Prof. Shigetoshi

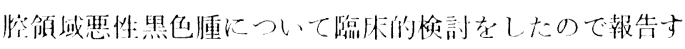
b.

対象 症 例

1970年から1989年の20年間に東京巨科料科大学蔝学部 第 1 口腔外科を受診し，覀性黑色腫と䛦断された20症例 老対象症例とした。

Shioda)

* Department of Dental Radiology, Faculty of Dentistry, Tokyo Medical and Dental University (Chief: Prof. Takahito Sasaki)

** Department of Clinical Laboratory, Faculty of Dentistry, Tokyo Medical and Dental University (Chief: Prof. Shigetoshi Shioda) 受付日: 平成 2 年11月20日 
表 1 口腔領域惡性黑色腫症例の年路, 性別

(1970 1989)

\begin{tabular}{|c|c|c|c|c|}
\hline 年路性别 & 男 & 性 & | 女 性 & 合計 $(\%)$ \\
\hline $30 \sim$ & & & i & $1(5)$ \\
\hline $40 \sim$ & 2 & 2 & & $2(10)$ \\
\hline $50 \sim$ & 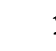 & 1 & 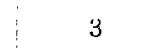 & $4(20)$ \\
\hline $60 \sim$ & 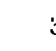 & 3 & 1 & $4(20)$ \\
\hline $70 \sim$ & 2 & 2 & 4 & $6(30)$ \\
\hline $80 \sim$ & 1 & 1 & 1 & $2(10)$ \\
\hline $90 \sim$ & & & 1 & $1(5)$ \\
\hline 合計 & 9 & 9 & 11 & $20(100)$ \\
\hline
\end{tabular}

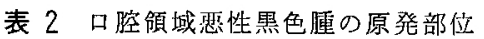

(1970 1989)

\begin{tabular}{|c|c|c|}
\hline \multicolumn{2}{|c|}{ 部 位 } & 症例数 $(\%)$ \\
\hline 上 顎 & 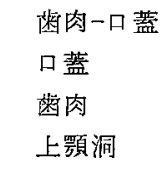 & $\begin{array}{r}10(50) \\
6(30) \\
2(10) \\
1(5)\end{array}$ \\
\hline 下 顎 & 歯肉 & $1(5)$ \\
\hline & 計 & $20(100)$ \\
\hline
\end{tabular}

\section{研究方法}

対象症例20例心ついて, 初診時の臨床所見, 肉腿的所 見, 病理組織学的所見, 治療法, 扣よび経過, 転帰につ いて検討した。

結果

\section{1. 年齢および性別}

年齢は32 92 歳に及び，50 歳台扣よび 60 歳台各 4 例

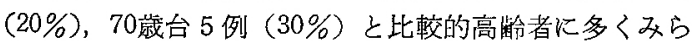
れた（表1）．性別では男性 9 例，女性11例であった。

\section{2. 原発部位}

上䫇齿肉から口蓋に及ぶ症例が 10 例 $(50 \%)$, 口蓋に 限局したすのが 6 例 $(30 \%)$ ，上買雨肉が 2 例 (10\%)

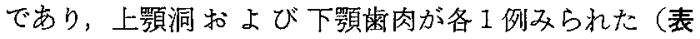
2).

\section{3. 肉眼所見 (臨床視診像)}

肉眼所見に基ずき20例を以下のごとく分類した。

1) 黒色結節型

黑色腫瘤病変を主とし，周四に色素斑を伴わない（1 例), (写真 1 ).

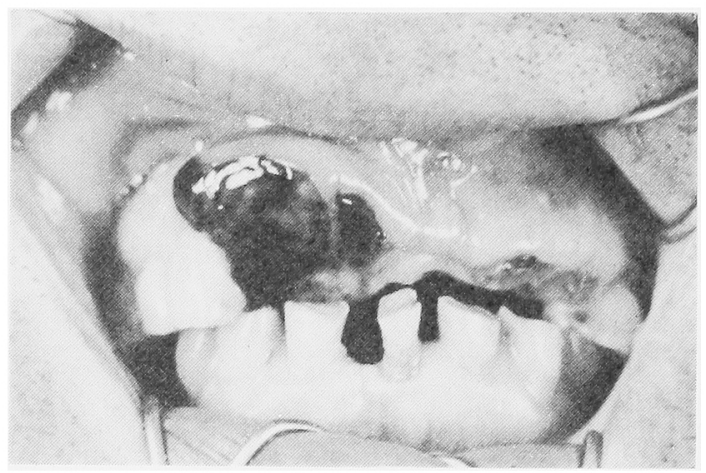

写真 1 黑色結節型

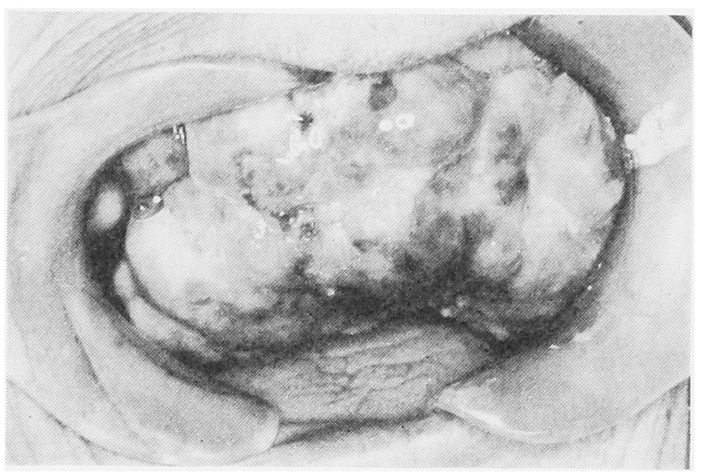

写真 2 無色蓕性結節型

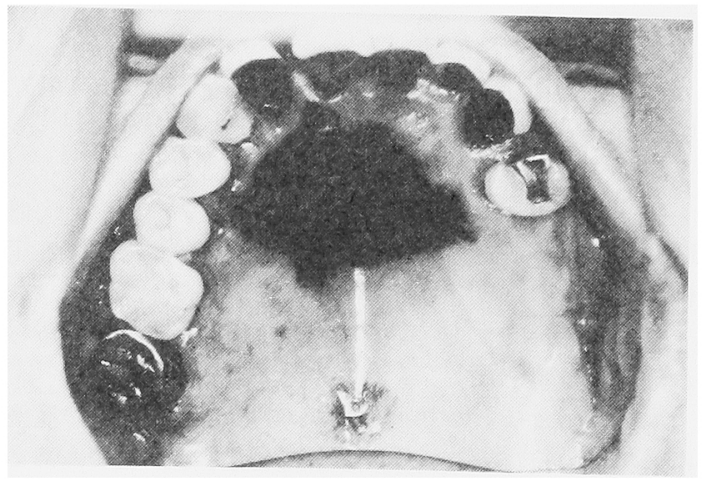

写真 3 斑状型

2）無色素性結節型

無色素性腫瘤病変を主にし，周囲に色素斑を伴わない (4 例), (写真 2 ).

3) 斑状型

顕著な腫瘤はみられず，色素斑を主病策とする（2 例), (写真 3 ).

4) 黒色混在型

黑色腫瘤病変安主にし，周囲に色素斑艺伴与（10例）， (写真 4 ). 


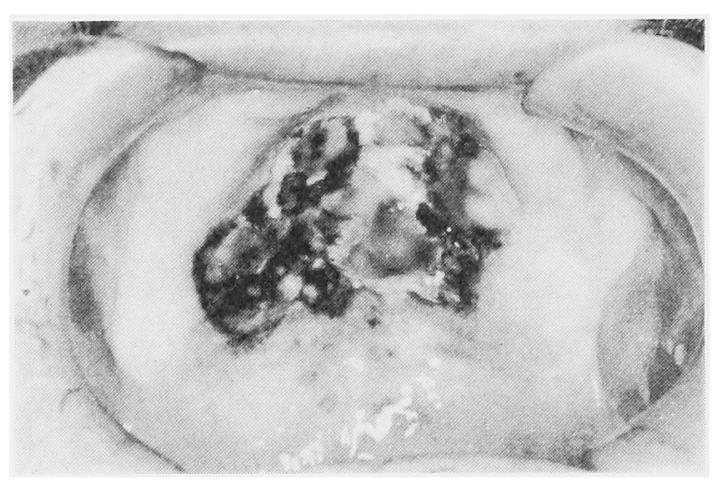

写真 4 黑色混在型

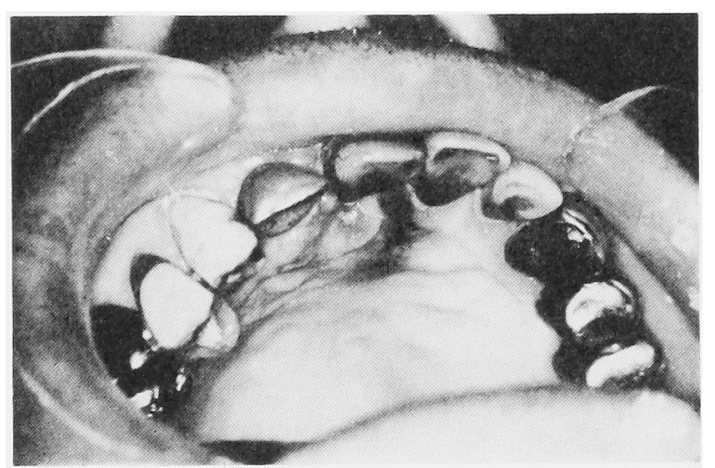

写真 5 無色素性混在型

\section{5）無色素性混在型}

無色素性腫溜がみられ，周囲に色素斑を伴う（ 3 例），

(写真 5 ).

\section{4. 病理組織学的所見}

腫㻛組織には紡䤵型の細胞 (spindle 型) と類上皮細 胞 (epitheloid 型) がみられ，無色素性腫溜を有する症 例では紡鉭形の細胞が多くみられた（写直 $6 ， 7 ）$.

表層粘膜上皮には上皮脚の延長などの過形成が認めら れ，黒色腫瘤を有する症例で影著であった。

細胞間結合 (Junctional activity) は，約半数の症例 にしか認められず，無色秦性腫瘤を有する症例ではあま りみられなかった（写真 7)，照色腫溜に色素斑を伴う 症例では細胞間結合は影著认認められた。

色瑟斑炕ついては，浸潤部に近い部位では基底層に大 型の異型メラノサイト, 明細胞の密な増生を認め, 上皮 の過形成,メラニン貪食細胞の浸潤がみられた。しか し，色素斑辺縁部に扣いては上皮の過形成，多くのメラ ノサイトを認めるが，基底層に批けるィランサイトの細 胞異型, 密度が低く、これらが腫瑝細胞の浸潤なのか, あるいは単にィラノサイトの過形成なのか爁別は困難で あった。

細胞の異型性, 細胞分裂指数 (Mitotic index) は症例

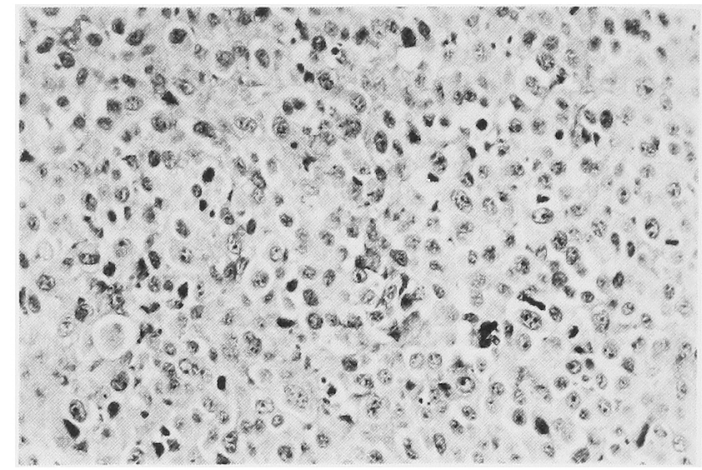

写真 6 班状型の病理組織像

類上皮細胞が多くみられる(H-E 染色, ×130).

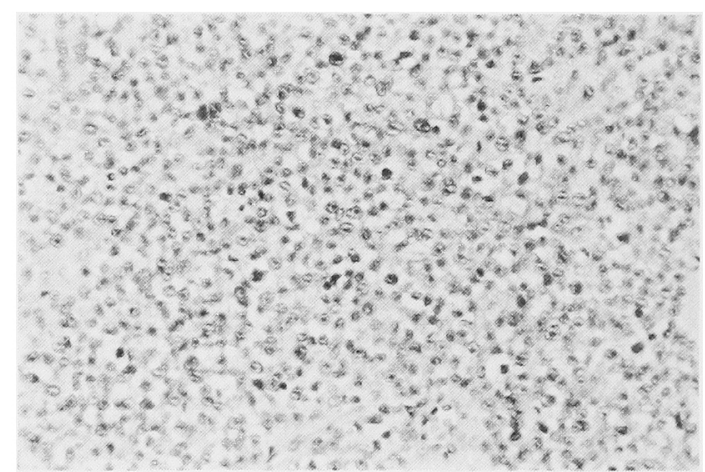

写真 7 無色素性結節型

紡銼型の細胞が多くみられ，稩胞間結合はあまり反 られない(H-E 染色, ×130)。

\section{により盖異が著しかった。}

\section{5. 臨休経過}

1) 治療法

不治療の 2 例を除き，全例の原発栄飞対して放射線療 法が施行されて物り，さらに外科療法を施行したのは 3 例であった。原発策治癒例は，この外科療法を施した 3 例の他に 6 例あり, 総計 9 例であった（表 3 ).

頸部リンパ節や遠隔藏器への枟移紧に対しては，放射 線療法を施したものが 9 例あり，そのうち 4 例で外科療 法 (頸部郭清術 3 例，頸部りン八節摘出術 1 例) 6行わ れた（表 4). その他の 6 例の 転移栄に 対しては, 外科 療法, 化学療法, 免疫療法が行われた。枟移巣治痛例は 放射線療法学独例 1 例, 放射線 十外科療法 1 例の 2 例の みであった。

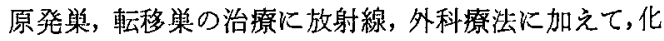
学療法, 免疫療法が行われた。化学療法としては，5-FU $(300 \mathrm{mg} /$ 日，内服あるいは2 $250 \mathrm{mg} /$ 日, 動注し総計1,750 $\mathrm{mg}$ )，DTIC (1クール，500 mgで1から4クール施 行）が用いられ，免痹療法としては，BCG，OK-432が 
表 3 口腔頒域恶性黒色腫の治療法（1970～1989）

\begin{tabular}{|c|c|c|c|c|c|}
\hline & 治療法 & 症例数 & 原発单治瘾 & 転移 & 生存期間 \\
\hline \multirow[t]{5}{*}{ 外科非併用群 } & $\mathrm{R}$ & 3 & 2 & 2 & $14 \mathrm{Y} 3 \mathrm{M}, \quad 4 \mathrm{Y}, \quad 1 \mathrm{Y}$ \\
\hline & $\mathrm{R}+\mathrm{I}$ & 3 & 1 & 2 & $8 \mathrm{Y} 4 \mathrm{M}, \quad 6 \mathrm{M}, \quad 3 \mathrm{M}$ \\
\hline & $\mathrm{R}+\mathrm{C}$ & 1 & () & 1 & $10 \mathrm{M}$ \\
\hline & $\mathrm{R}+\mathrm{I}+\mathrm{C}$ & 2 & 1 & 2 & $6 \mathrm{Y} 3 \mathrm{M}, \quad 2 \mathrm{Y} 6 \mathrm{M}$ \\
\hline & $\mathrm{R}+\mathrm{I}+\mathrm{C}+\mathrm{H}$ & 2 & 1 & 2 & $1 \mathrm{Y} 9 \mathrm{M}, \quad 8 \mathrm{M}$ \\
\hline \multirow[t]{5}{*}{ 外科件用群 } & $\mathrm{R}+\mathrm{S}$ & 3 & 2 & 3 & $4 \mathrm{Y}, 3 \mathrm{Y} 11 \mathrm{M}, 7 \mathrm{M}$ \\
\hline & $\mathrm{R}+\mathrm{S}+\mathrm{C}$ & 1 & 0 & 1 & $7 \mathrm{M}$ \\
\hline & $\mathrm{R}+\mathrm{S}+\mathrm{I}$ & 1 & 1 & 1 & $3 \mathrm{Y}$ \\
\hline & $\mathrm{R}+\mathrm{S}+\mathrm{I}+\mathrm{C}$ & 1 & 0 & 1 & $1 \mathrm{Y} 3 \mathrm{M}$ \\
\hline & $\mathrm{R}+\mathrm{S}+\mathrm{I}+\mathrm{C}+\mathrm{H}$ & 1 & 1 & 1 & $3 \mathrm{Y} 8 \mathrm{M}$ \\
\hline
\end{tabular}

$\mathrm{R}$ ：放射線療法 $\mathrm{S}$ ：外科療法 $\mathrm{C}$ ：化学療法 $\mathrm{I}$ ：免疫療法 $\mathrm{H}$ ：温熟療法

表 4 外科併用群の臨床経過

\begin{tabular}{|c|c|c|}
\hline & 原発笨, 治療法 & 譼床経過 \\
\hline 1 & $\begin{array}{l}\text { 上顎遒肉 } \\
\text { 口蓋 }\end{array}$ & 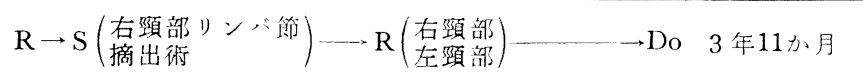 \\
\hline 2 & $\begin{array}{l}\text { 上顎䛧肉 } \\
\text { 口蓋 }\end{array}$ & $\mathrm{R} \rightarrow \mathrm{S}($ 右頸部部消術 $) \longrightarrow \mathrm{R}\left(\begin{array}{l}\text { 右鎖骨部 } \\
\mathrm{I}\left(\begin{array}{l}\text { 胸骨部など } \\
\text { 全身転移部 }\end{array}\right) \longrightarrow \rightarrow \text { (全身転移) }\end{array}\right.$ \\
\hline 3 & $\begin{array}{l}\text { 上顎终肉 } \\
\text { 口蓋 }\end{array}$ & 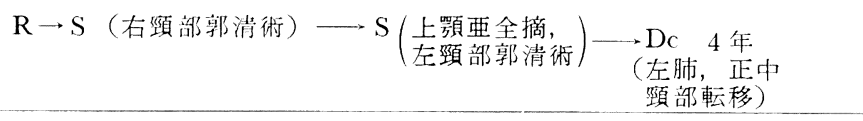 \\
\hline 4 & 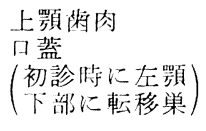 & 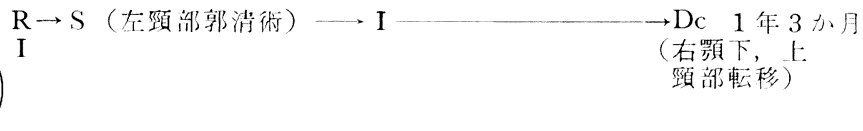 \\
\hline 5 & 口苗 & 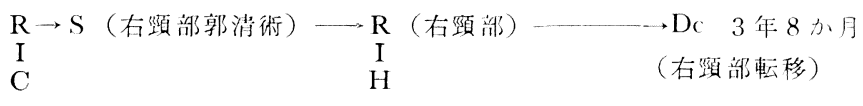 \\
\hline 6 & 口蓋 & $\begin{aligned} & \mathrm{R} \rightarrow \mathrm{S} \text { (上䫇亜全摘） } \longrightarrow \text { Dc } 7 \text { か月 } \\
& \text { (全身転移) }\end{aligned}$ \\
\hline 7 & 1. 顎洞 & $\begin{array}{l}\mathrm{R} \\
\mathrm{C}\end{array} \rightarrow \mathrm{S}\left(\begin{array}{l}\text { 右上顎摘出街 } \\
\text { 右㥧部郭清術 }\end{array}\right)$ \\
\hline
\end{tabular}

用いられた。近年は 3 例に温熱療法も搠用された（表 3 ).

2) 経過・転㷌

今回検索した20例中16例において枟移が確認され，15 例腫痬死した。他病死は 3 例であり, 腫瘍の再発なく生 存しているものが 1 例, 転移栄病変を有与るも生存して いるものが1例みられた。

Kaplan-Meier 法により生存率を算出すると，初骖よ り最長14年 3 か月の生存例子又られたが，3年生存率
$46.6 \%, 5$ 年生存率 $26.6 \%$ であった（表 5 ）.

外科做用群の 7 例, 外科非併用群の 11 例孝比較する と，前者では生存期間は初診より7 月から 4 年であ り，後者では1か月から14年 3 か月であった。さらに， 外科僧用群で 3 年以上の生存例では，1例を除いて 3 例 において，原発巣は放射線療法により制御されており， 頸部リン八節転移に対しては頸部郭清術が施行され, さ らに術後放射線療法が施行された（表 4 ）.

肉腿所見による各群においては，1例の黑色結節型で 
表 5 口腔領域患性黒色腫の生存率（1970～1989）

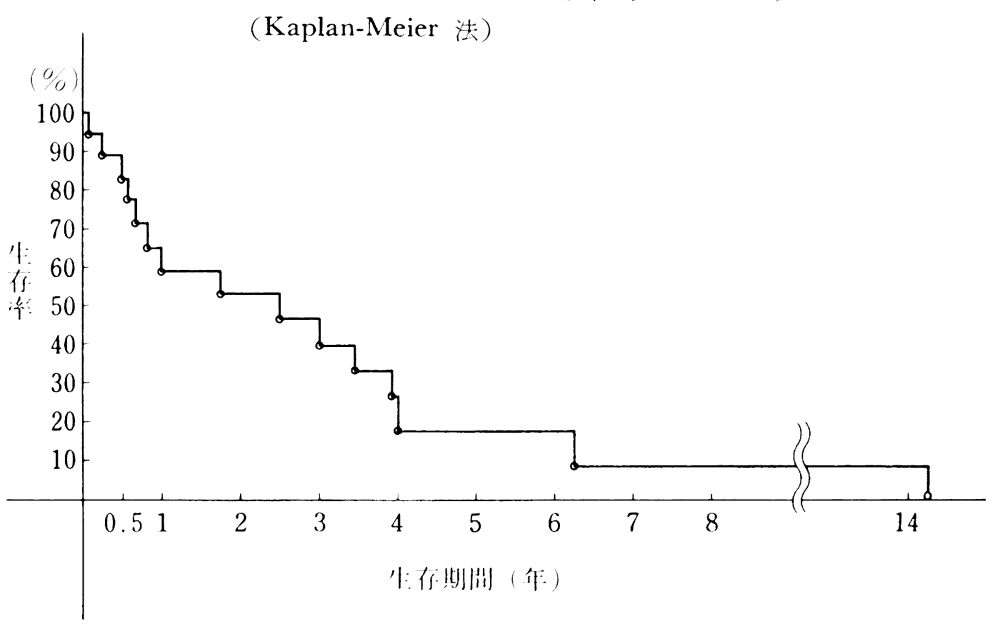

は坐存期間は 3 年11か月であり，無色素性結節型 4 例て は1〜8か月であった。 2 例の斑状型では，14年 3 か 月, 2 年 2 か月であり, 後者は現在, 転移栄病変を有す るが生存中である。10例の黑色混在型では， 6 か月から 8 年 4 か月であり，3 例の無色素性混在型では， 6 年 3 か月，4年，1年であった。

\section{考察}

口腔领域の恶性黑色腫はきわめてまれで，欧米ではす ベての恝性黑色腫の0.2 8\%といわ机ている1)が，わが 国ではその此率は高く，高木ら $12.4 \%$ と報告している.

皮居科領域の悪性黑色腄症例は多く，数多くの研究報

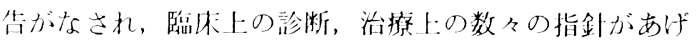
られている4,5). 口腔領域の悪性蛒色腫においては, 症例 数が少ないこともあり，この皮败科領域で得られた結果 金礎として栖々の診断, 治療が試みられている。

しかし，皮闻原発の昰性黑色腫と口腔粘膜原発の悪性 黑色腫とでは，その生物学的性状が必ずしも一致せず， 口腔粘膜原発悪性黑色腫独自の診断基準，治拯法を確立 するための柆罙が必要である。

今回，過去20年間に当科に米院した口腔领域悪性黑色

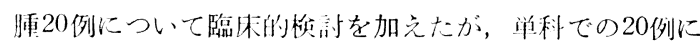
及ぶ臨床的蚞封の報告は数少なく，多くは文献的報告例 を多数集め检索している6 10)

今回経験した20例に拈いては，性差はなく，高粭者に 多かったことは諸家の報告6,10,11) と一致するところであ り，また発生部位においても，上顎蔌肉から几蓋にかけ て最も多く㕕られ，既報告6,10 12) と同様である。口腔領 域では，文献们に当科で少られなかった舌，口底，口庯
の悪性黑色腫が報告されている ${ }^{13 \sim 16)}$

皮虞科領域の悪性黑色腫については，臨床像と組織像 により分類がなされている17)。すなわち, 悪性黑子型 (Lentigo maligna melanoma; LMM), 表在挔大型 (Superficial spreading melanoma; SSM), 結節型 (Nodular melanoma; NM), 末端黑子型 (Acral lentiginous melanoma；ALM）に分類され，口腔領域の悪性黑色腫は， 腫瘤を形成し周囲に平坦な色素斑を伴い，臨床的に進行 が早く子後が不良のものが多いことから，ALM に属す るものが多いとされてきた18,19) しかし, 今间の㭘索の よらに, 肉腿所見においても多椂であり, 組織発生を考

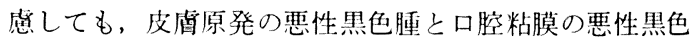
腫を同一視するのは疑問が残り，その生物学的性状も異 なることを示唆する報告 ${ }^{10,20,21)}$ 女みられることから，口

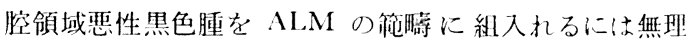
があるよに思われる。 Rapini ら ${ }^{10)}$ は口腔领域の慗性: 黒色腫で ALM と同㨾に色素攻を伴らものに刘して, ALM といら呼称に周執せずに, malignant melanoma with radial growth phase としたうがよいとし,さらに 口腔粘膜原発悪性黑色腫について, 独自の分類の確立, 子後因子などについて検討すべきたとしている，最近で は, Peckitt ら ${ }^{22)}$ は, 表皮基底層から皮下脂肪組織まで の各曆への浸洞度別にその病栄を分類した Clark の分 類 ${ }^{23)}$, 表皮から下部へ $0.76 \mathrm{~mm}$ 以下，あるいはそれ以

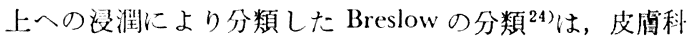
領域の悪性黑色腫の子後を推測するのには有効である が，口腔領域恶性黒色腫に対しては相関閔係をみいだせ ないとしている。このような状況のもとで, 今回われわ れは, 一伍案として, 主に腫痬の肉眼所見により黑色結 節型, 無色素性結節型, 斑状型, 黒色混在型, 無色素性 混在型の 5 型の分類を提示した。それでれの型により生 


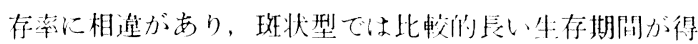

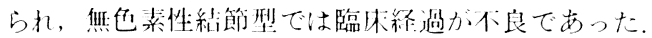

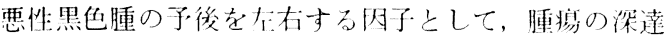

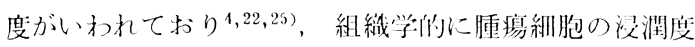
をみるのは重要ではあるが，要性黑色腫は治胳前の生検 については慎重な対処が望まれ，その㭘索にも限界があ ると思われる。

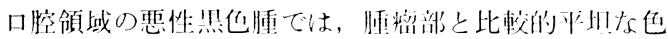
素琟が韲在，あるい:そのどちらかが単独にみられる。

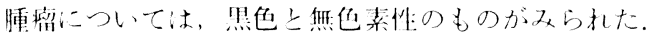

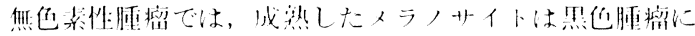

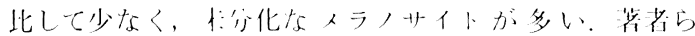

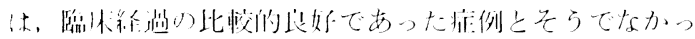

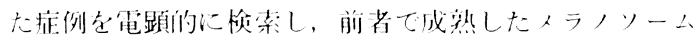

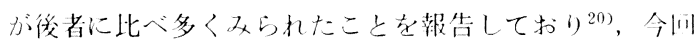

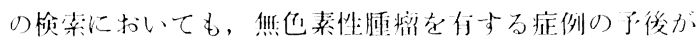

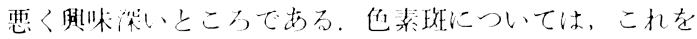
Rapini $5^{10}$ 汢, radial growth phase 之呼び, 蕾捥の水

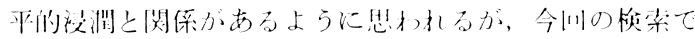

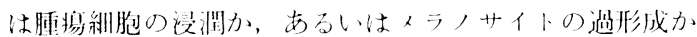

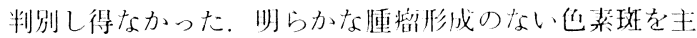

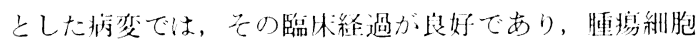
の活性が他に比して低いと思われた。

治療法については，これまで第一次選択として外科療 法があげられている。皮有科領域に拈ける悪性胃色腫で は，切除箱囲を腫演周囲 $2 \mathrm{~cm}$ ないし $5 \mathrm{~cm}$ といわれ，広 範曲な切除の必要性が説かれている5）しかし，これを 口腔領域のそれにあてはめようとしても，必ずしもその ような広範井な切除が可能な症例ばかりではなく，その ため切除範围が小さくなり，近に腫陽を刺激してその進 展，転移を促進させる可能性もある。このよ5な理由に

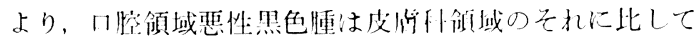
予後が琶いとする報告わもある。今回顺索した症例中， 外科併用辟では 4 年以上の生存症例はみられず，しかも 外科療法後は最長でも2 年以内に死亡している。当科で は全症例とも術前に放射楾療法が施されているが，外科

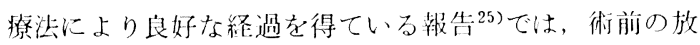
射線療法などの療法がなされておらす，術前の治搌，手 術までの胡間が術後の経過に影犁しているのかもしれな い.

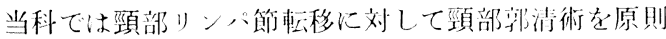
として施行して扣り，今川検热した症例のらちの1例は

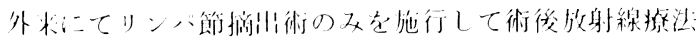

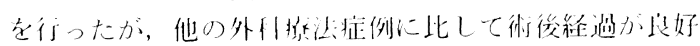
であるのは舆味体

放射線撩法については，元未，覀性黑色腫は放射線抵 抗性であり，姑息的治療としての傾向が強く，根治的治 療とはなり得ないとされており，口腔領域の曹吽黑色腫

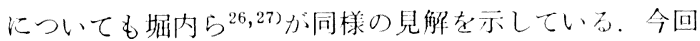

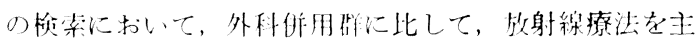

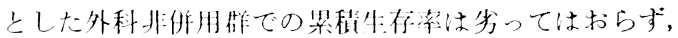
術後の機能障害などを考虑するともしる放射線療法の有

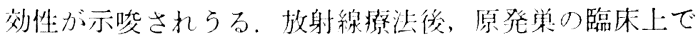
の完全消失が 9 例に2られた。リン、節転移に刘与る頸

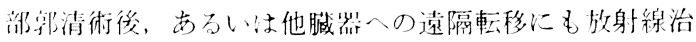
据が施されたが，根治的治痖とはならなくても十分な延

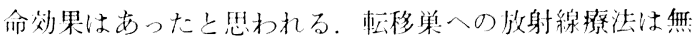

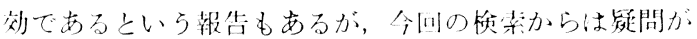

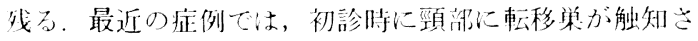

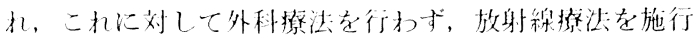
したところ，原発栄とともに侩移为も消失した。その㷋

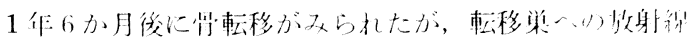

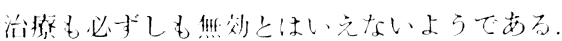

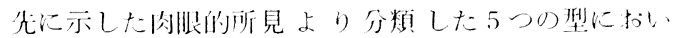
一，放射楾に感受性が高いのは想色斑を主とする玨状型

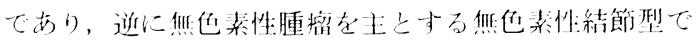

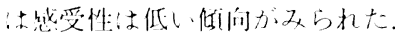

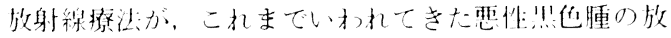

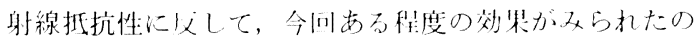

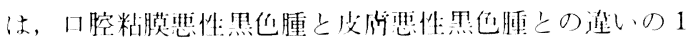
つを表しているのかもしれない。

20 例中16例て転移が碓偲され，11悾領域慙性黑出腫の 易枟移性が示された。梅田ら ${ }^{25}$ は, 転移栄への放射線治 帱により缩主の免疫能が低下し，耘移が促進されるとし ているが，今倦の颃技必要であると思われる。

結語

1970年から1989年にいたる20年間に東京医科料科大学

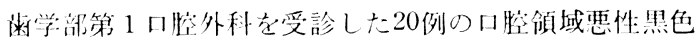

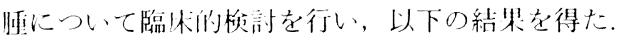

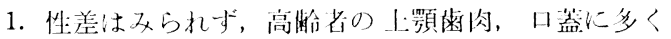
みられた。

2. 肉眼的所見上り, 黑色結節型, 無色素性絬節型, 玟状型，黑色混作型，無色丞性混在型の5型に分類さ 九，整状型では臨㦿経過が比挍的良好であり，逆に想色 素性結節型では生存期間は短かかった。

3. 口腔領域の盾平上皮癌, 腺采腫瘳に比して全般们

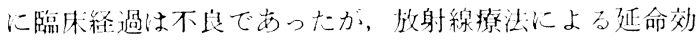
果が示崚された。

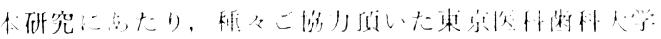

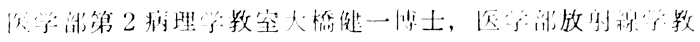
等滥谷均助教授に深く感旃いたします。

本論文の要旨恃, 第14回頭頙部腫疾学会(平成 2 年 6 月，宇都宮）、符 49 回日本瘦学会総会（平成 2 年 7 月，

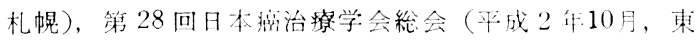
宗）にて発表した。 


\section{引用文 献}

1) Hormia, M. and Vuori, E.E.J.: Mucosal melanoma of head and neck. J Laryngol 83: 349-359 1969.

2) 高木夷, 石川梧的：日本人に扣ける口腔粘膜 原発の悪性黑色腫。口病誌 38: 391-403 1971.

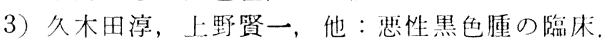
皮店科の臨林 3：519-528 1961 .

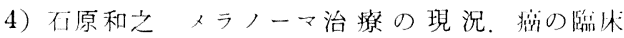
25: 741-746 1979.

5）石原和之, 池川修一：䜀性黑色腫の診断と治䝤. 癌と化学療法 12：1727-1734 1985.

6) Takagi, M., Ishikawa, G., et al.: Primary malignant melanoma of the oral cavity in Japan. Cancer 34: 358-370 1974.

7) Liversedge, R.L.: Oral malignant melanoma. Br J Oral Surg 13: 40-55 1975.

8）中久木和也, 加藤雅典, 他：口腔原発思性黑色 睡。耳鼻監床 70：953-969 1977.

9) 梅田正博, 寺延治, 他：口腔粘膜原発㤮性黑 色腫の治療法と予後。日癌治誌 25：2499-2510 1990.

10) Rapini, R., Golitz, L.E., et al.: Primary malignant melanoma of the oral cavity. Cancer 55: 1543-1551 1985.

11）消水正嗣, 小浜源郁監修：口腔瘦。デンタルダ イヤモンド社, 東京, 1989, 336-345頁.

12) Chaudhry, A.P., Hampel, A., et al.: Primary malignant melanoma of the oral cavity. Cancer 11: 923-928 1958.

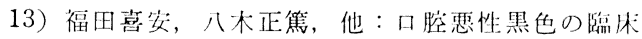
病理学的検捨 (抄)。 口外誌 35 ：3168-3169 1989.

14) Moore, E.S. and Martin, H.: Melanoma of the upper respiratory tract and oral cavity. Cancer 8: 1167-1176 1955.

15）茂木健司，斎藤晃一，他。患性黑色腫 8 例の臨

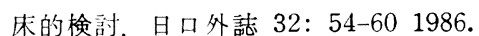

16) Regezi, J.A., Hayward, J.R., et al.: Superficial melanomas of oral mucous membranes. Oral Surg 45: 730-740 1978.

17) 中島 孝: 虫性黒色腫の病理。病理と臨休 5: 1095-1102 1987.

18）梅田正博, 寺延 治, 他：口腔粘膜原発患性黒 色腫の臨床的・病理組織学的検討第 1 報：自 睮例 9 症例の組織学的特徵について。日口外誌 33: 1991-1999 1987.

19) MacDonald, J.S., Miller, R.L., et al.: Acral lentiginous melanoma of the oral cavity. Head and Neck Surg 5: 257-262 1983.

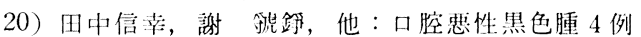
の電子顕砫鏡学的研究。 日只外誌 35: 97-102 1989.

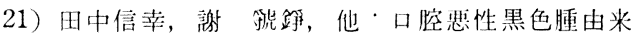

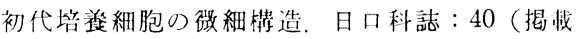
予定)。

22) Peckitt, N.S., Wood, G.A., et al.: Malignant melanoma of the oral cavity. Oral Surg 70: 161-164 1990.

23) Clark, W.H., Anisworth, A.M., et al.: The developmental biology of primary human malignant melanomas. Semin Oncol 2:83-103 1975.

24) Breslow, A.. Thickness, cross-sectional areas, and depth of invasion in the prognosis of cutaneous melanoma. Ann Surg 172: 902-908 1970.

25）梅田正博, 寺延 治, 他：口腔粘膜原発悪性黒 色腫の臨休的・病理組織学:的検討第 2 報：治 療法と予後について。 日外誌 33：1822-1828 1987.

26）堀内淳一・垫性黑色腫（口㓐粘膜）の放射線治 療。瘦の臨林 18：639-643 1972.

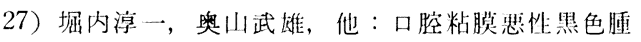
7 例の放射線治療経駼。臨林放射線 15：4044121970. 